\title{
İş Sağlığı ıe Güvenliği Kanunu ve İşyerlerinde Acil Durumlar Hakkında Yönetmelik Kapsamında İşverenin Yükümlülüğü
}

\author{
Mustafa Kağan İzmirli ${ }^{1}$, Zeynep Feride Olcay ${ }^{2 *}$, Ahmet Ebrar Sakalli ${ }^{3}$ \\ ${ }^{1}$ İstanbul Aydın Üniversitesi, Lisansüstü Eğitim Enstitüsü., Özel Hukuk Anabilim Dalı (Doktora Öğrencisi), İstanbul, Turkey, (ORCID: 0000-0001-5849-4697), \\ mustafa.izmirli@stu.aydin.edu.tr \\ 2* İstanbul Aydın Üniversitesi, Anadolu Bil MYO., İș Sağlı̆̆ı ve Güvenliği Programı, İstanbul, Turkey, (ORCID: 0000-0001-5720-7350), zeynepolcay@aydin.edu.tr \\ ${ }^{3}$ İstanbul Aydın Üniversitesi, Anadolu Bil MYO., İş Sağlığı ve Güvenliği Programı, İstanbul, Turkey, (ORCID:0000-0003-0445-0722), ahmetsakalli@aydin.edu.tr
}

(İlk Geliş Tarihi 1 Şubat 2021 ve Kabul Tarihi 24 Nisan 2021)

(DOI: $10.31590 /$ ejosat.902275)

ATIF/REFERENCE: İzmirli, M.K., Olcay, Z.F. \& Sakallı, A.E. (2021). İş sağlığı ve güvenliği kanunu ve işyerlerinde acil durumlar hakkında yönetmelik kapsamında işverenin yükümlülüğ̈̈. Avrupa Bilim ve Teknoloji Dergisi, (23), 810-816.

\section{$\ddot{O} \mathbf{z}$}

İş Sağlığı ve Güvenliği Kanunu ve bu kanuna bağlı olarak çıkarılan “İşyerinde Acil Durumlar Hakkında Yönetmelik”, işverenlere acil durumlarla ilgili olumsuz etkilerden çalışanları ve işyerini korumak için bir takım düzenlemeler yapmasını zorunlu kılmıştır.

Acil durumlarla ilgili araştırmalarda mesleki uygulamanın nasıl geliştirilmesi gerektiği ile ilgili odaklanan çalışmalar oldukça azdır. Bu çalışmada, 6331 Sayılı İş Sağlığı ve Güvenliği Kanunu kapsamında işverenlerin genel yükümlülükleri ile işyerinde ilgili mevzuat bünyesinde gerçekleşen acil durumlar ile ilgili yükümlülükleri ve acil durumlar kapsamında yapılması zorunlu olan ve önemli bir yere sahip olan acil durum eylem planının nasıl hazırlanması gerektiği irdelenmiştir. Bunun yanında dünyada acil durumlarla ilgili güncel yaklaşımlar verilmiştir.

Anahtar Kelimeler: 6331 Sayılı İş Sağlığı ve Güvenliği Kanunu, İşçi Sağlığı ve İş Güvenliği, İşverenin Yükümlülüğü, Acil Durum Yönetimi, Acil Durum Planı.

\section{Employer's Liability within the Scope of Occupational Health and Safety Law and Regulation on Emergency Situations in Workplaces}

\begin{abstract}
The Occupational Health and Safety Law and the regulation on workplace emergencies issued in depending this law obliges employers to make some regulations to protect employees and the workplace from negative effects related to emergencies.

There are very few studies that focus on how professional practice should be improved in research on emergencies. In this study, it is examined the general obligations of employers within the scope of occupational health and safety law no. 6331, their obligations regarding emergencies that occur within the relevant legislation in the workplace and how to prepare the emergency action plan, which has an important place. In addition, current approaches to emergencies around the world are given.
\end{abstract}

Keywords: Law of Occupational Health and Safety numbered 6331, Worker's Health and Work Safety, obligation of the employer, Emergency Management, Emergency Plan. 


\section{Giriş}

İşyerlerinde iş sağlığı ve güvenliğinin (İSG) oluşturulması ve hali hazırda uygulanmakta olan güvenlik ve sağlık önlemlerinin sürekli geliştirilmesi için hem işverenler, hem de çalışanların görevleri, yetki, sorumluluk, hak ve yükümlülüklerinin düzenlenmesi amacıyla 2012 yılında yayımlanmış olan 6331 Sayılı İş Sağlığı ve Güvenliği Kanunu'yla (ISSGK) ülkemizde İSG konusunda yeni bir dönem başlandığı söylenebilir.

Elbette 6331 sayılı Kanun'dan önce de ülkemizde işyerlerinde İSG ile ilgili düzenlemeler mevcuttu. Ancak bu kurallar, oldukça dağınıktı; diğer yandan, bu kuralları harekete geçirecek, uygulanmasını sağlayacak, bakanlıklar, belediyeler, sosyal güvenlik kurumu gibi kamu kurum ve kuruluşları da dağınık ve birbiri ile ilişkisizdi (Süzek, 1985; 62). İSG, çalışma hayatında karmaşık bir olgudur (Ozay ve Coskun, 2017: 375). Bu karmaşıklıklardan bir tanesi de işyerindeki acil durumlardır.

Avrupa Birliği'nin (AB) uzun yıllardır İSG konusuna ve İSG konusunun temel sorunsalı olan iş kazalarına büyük önem vermesi ve $A B$ üye ülkelerinin konuya özgü kanunlarının bulunmasından dolayı, $\mathrm{AB}$ uyum süreci için gerekli görülen münferit bir İSGK'nın yürürlüğe girmesi zorunlu olmuştur. Sadece AB uyum süreci için değil aynı zamanda ülkemizde yaşanan ölümlü ve yaralanmalı iş kazalarının sayılarındaki artış, dünyada ölümlü iş kazalarında üçüncü sırada, Avrupa'da ise birinci sırada bulunmamız da müstakil İSGK çıkarılmasının gerekliliğini ortaya koymuştur.

Çalışma hayatını düzenlemek amacıyla ülkemizde ilk kez 1936 yılında çıkarılmış olan 3008 sayılı İş Kanununun (İK) 54.maddesinden 62.maddesine kadar İSG ile ilgili hükümler bulunmaktadır (3008 Sayılı İK, 1936). 3008 sayılı İK'dan sonra çıkarılmış olan 931 sayılı İK'da da İş Sağlığı ve güvenliğiyle ilgili hükümler yer almaktadır (931 Sayılı IK, 1968). 931 Sayılı İK'nın Anayasa Mahkemesi tarafından iptali ve sonrasında yürürlükten kaldırılmasının ardından çıkarılan 1475 Sayılı yeni İK'da, 931 Sayılı İK madde sayıları değiştirilmemiştir, sadece birkaç noktada değişiklik yapılmıştır.(Tunçomağ, 1972: 244). 1475 Sayılı İK'da , kanuna bağlı çıkarılmış tüzük ve yönetmeliklerle İSG konusu daha geniş perspektiften değerlendirilmiştir (1475 Sayılı İK, 1971).

1475 Sayılı İK'dan sonra çıkarılan 4857 Sayılı İK'nın beşinci bölümünde İş Sağlığı ve Güvenliği başlığı altında 77.maddeden, 90.maddeye kadar İSG ile ilgili hükümler yer almaktaydı (4857 Sayılı İK, 2003). Halen yürürlükte olan 4857 sayılı Kanun ile İSG konusu hukuki düzenleme bağlamında ilk kez önleyici bir yaklaşımla ele alınmıştır (Özdemir, 2014: 1).

4857 sayılı İK ve buna uygun hazırlanan Yönetmelikler 6331 sayılı İSGK'nın kabul edildiği tarihe kadar değişikliklerle “işçi”ler hakkında uygulanmıştır. 20 Haziran 2012 tarihli Resmi Gazete'de yayımlanarak kademeli olarak yürürlüğe giren 6331 sayılı İSGK ise Anayasamızın 49. maddesinde de olduğu gibi “çalışanların” hukukunu güvence almaktadır (Özdemir, 2014: 1).

4857 sayılı İK'nın İSG ile ilgili hükümlerinde ileri düzeyde gelişmeler olsa dahi, 2012 yılında yayımlanan müstakil İSGK ile ayrı bir düzenlemeye kavuşturulan ISG hükümleri 4857 Sayılı İK'dan çıkartılmıştır (İSGK, 2012). 6331 sayılı İSGK, iş kazaları ve meslek hastalıkları yaşanmadan, tehlikelerin kaynağında yok edilmesini amaçlayan önleyici bir yaklaşıma sahip olarak düzenlenmiştir (Korkmaz ve Avşallı, 2012; 153).
AB ve Uluslararası Çalışma Örgütü (ILO) normlarına uyumlu olarak hazırlanan 6331 sayılı ISSK'nın getirdiği en önemli değişiklik; kamu ve özel sektör fark etmeksizin, faaliyet konularına, çalışan sayısı göz önünde bulundurulmaksızın, çıraklar ve stajyerler olanlar da dahil olacak şekilde tüm çalışanları kapsamı içine almasıdır. AB direktifleri ve ILO sözleşmelerinde, bazı istisnai durumların kapsam bakımından dışarıda bırakılması konusunda taraf/üye devletlere esnek hareket etme imkanı tanınmıştır. İSGK' da da, kendi adına bağımsız olarak çalışanlar ve bazı faaliyet alanları kapsam dışında bırakılmıştır.

Doktrinde, ISG mevzuatının katı hukuk metinleri halinde dondurulmaması, ayrıntılı kurallar yerine genel kurallarla yetinilmesi gerektiği ileri sürülmektedir (Süzek, 1985; 63). Bu görüşü savunanlara göre; teknolojideki hızlı değişim ve gelişim, yeni iş alanları ve bunlara bağlı olarak yeni mesleki risklerin ortaya çıkması, mevzuatta da gerekli değişiklik ve yeniliklerin yapılmasını zorunlu kılmakta; bu durum, yasa boşlukları nedeniyle İSG önlemlerinin gereği gibi yerine getirilmesinde zaafiyete sebebiyet vermektedir. $\mathrm{Bu}$ nedenle, uygulama esnekliğini sağlayabilmek için, özellikle teknik iş güvenliği önlemlerine ilişkin kuralların yasaların çizdiği genel çerçeve dikkate alınarak idari işlemlerle düzenlenmesinin uygun olacağ görüşü de ileri sürülmüştür

Ancak, işveren ve çalışanlarda iş sağlığg ve güvenliği bilincinin yeterince gelişmediği ülkelerde, sadece genel nitelikte düzenlemelerle yetinip, konuyu idari düzenlemelere birakmak sakıncalı bir yöntem olur (Süzek, 1985: 64). Bu ülkelerde, genel çerçeveyi belirleyen Kanun yanında, tarafların hak ve yükümlülüklerini açık, net, ayrıntılı 1 şekilde ortaya koyacak hukuk normlarına da ihtiyaç vardır. Nitekim, hukukumuzda da, iş sağlığı ve güvenliğini sağlayıcı genel kanun yanında, pek çok, tüzük ve yönetmelik ile yapılan işin özelliklerine göre, teknik ayrıntıları açıç̧a ortaya koyan daha özel hükümler öngörülmüş̧ür.

İşverenin, İSG önlemlerini alma konusundaki yükümlülüklerini belirleme bakımından da aynı durumu görmekteyiz. İş ilişkisinin genel hükümlerini oluşturan Türk Borçlar Kanunu'nda (TBK) işverenin ISG önlemlerini alma zorunluluğu, "İşveren, işyerinde iş sağlığı ve güvenliğinin sağlanması için gerekli her türlü önlemi almak, araç ve gereçleri noksansız bulundurmak; işçiler de iş sağlığı ve güvenliği konusunda alınan her türlü önleme uymakla yükümlüdür." şeklinde düzenlenmiştir (TBK md. 417/2).

6331 sayılı İSGK'da ise çalışanların sağlık ve güvenlik yönünden korunması için işverenin sorumluluğunun sınırları daha geniş tutulmuştur (Kılkış, 2013; 22). Kanunun "işverenin genel yükümlülüğü’” kenar başlıklı 4. maddesinde işverenin çalışanların işleriyle ilgili İSG şartlarını sağlama konusunda yükümlülüğü olduğu belirtilmiş, 1 . fikrada bu konudaki yükümlülükleri sıralanmış, 2-4 fikralarda ise işverenin sorumluluğunu ortadan kaldırama veya sınırlamaya yönelik durumlar bakımından kısıtlar öngörülmüştür. Keza kanunun aşağıda üzerinde durulan hükümlerinde de işverenin özel durum veya risklere ilişkin yükümlülükleri gösterilmiştir. 6331 Sayılı Kanun'da işverenin İSG önlemleri alma yükümlülüğünün sınırları büyük ölçüde genişletilmiş ise de özellik arz eden pek çok iş kolu veya risk alanlarına ilişkin işveren yükümlülükleri ayrıca çıkarılan yönetmelik ve tebliğlerle açıklığa kavuşturulmuştur. 


\section{6331 Sayılı Kanun'a Göre İșverenin Yükümlülükleri}

6331 sayılı Kanunun işverenin genel yükümlülüğünü düzenleyen 4. maddesi dişında öngörülen işveren yükümlülükleri aşağıda özetle ele alınmıştır.

İş Sağlığı ve Güvenliği Hizmetleri için gerekli ve yeterli eleman bulundurma yükümlülüğü: İşverenin tüm işyerlerinde iş güvenliği uzmanı, işyeri hekimi ile on ve ondan daha çok çalışanın bulunduğu, çok tehlikeli sınıfta yer alan işyerlerinde diğer sağlık personeli çalıştırma yükümlülüğü bulunmaktadır. Bahsi geçen hizmeti, uygun şartları sağladığı takdirde kendi çalışanları tarafından ya da Ortak Sağlık ve Güvenlik Biriminden (OSGB) hizmet alarak gerçekleştirebilir (İSGK, md.6/1, a).

Risk değerlendirmesi, kontrol, ölçüm ve araştırma yükümlülüğü: Yeni İSG yaklaşımının temelini oluşturan, iş kazaları meydana gelmemesi ve meslek hastalıklarının oluşmaması için önleyici yaklaşım anlayışı, işverene risk değerlendirmesi yapmak ya da yaptırmak yükümlülüğünü de getirmiştir (İSGK, md. 10/1). İSGK md. 10/4'e göre, “İşveren iş sağlı̆̆ ve güvenliği yönünden çalışma ortamına ve çalışanların bu ortamda maruz kaldı̆̆ $\mathrm{risklerin} \mathrm{belirlenmesine} \mathrm{yönelik} \mathrm{gerekli}$ kontrol, ölçüm inceleme ve araştırmaların yapılmasına imkan sağlar".

Acil Durum Planları hazırlama, Yangınla Mücadele ve İlk Yardım önlemleri alma yükümlülüğü: İşveren risk değerlendirmesi çalışmaları ve tehlikelere karşı aldığı önlemlere rağmen çıkması olası yangın, ilkyardım gerektirecek olaylar gibi acil durumları belirlemekle yükümlüdür. Aynı zamanda belirlemiş olduğu meydana gelmesi muhtemel ve mümkün acil durumları önlemek veya zararlarını azaltmak yönünde gerekli çalışmaları yapmak ve işyeri acil durum planını hazırlaması zorunludur (İSGK, md. 11/1, a, b).

İş kazası ve meslek hastalıklarının kayıt ve bildirimi yükümlülüğü: İSGK 14.maddesine göre işveren çalışanlarıyla ilgili tüm iş kazası ve meslek hastalıklarına dair kayıtları tutmalıdır. Ayrıca, kendisine bildirimi yapılan meslek hastalıkları için işveren öğrendiği tarihten itibaren 3 iş günü içinde, işyerinde yaşanan iş kazalarını da yine kazadan sonraki üç iş günü içinde Sosyal Güvenlik Kurumuna bildirme zorunluluğu bulunmaktadır (İSGK md. 14/1, 2, a).

Sağlık gözetimi yükümlülüğü: İşveren, çalışma ortamında maruz kalacakları ISG risklerine göre çalışanların sağlık kontrolü ve gözetimi yapılmalarını sağlar (İSGK, md. 15/1, a) . Bu bağlamda, işveren, çalışanların işe girişlerinde, iş değişikliği yaptıklarında, iş kazası ya da meslek hastalığı söz konusu olduğunda veya sağlı nedeniyle işyerinden bir süre ayrı kaldıklarında işe döndükleri zaman talep etmeleri durumunda ve işyerinin tehlike sınıfına göre Bakanlık tarafından belirlenmiş olan düzenli aralıklarla sağlık kontrollerini yaptırmak ve buna ilişkin tüm maliyetleri karşılamakla yükümlüdür (İSGK, md. $15 / 1, b)$.

Çalışanların bilgilendirilmesi yükümlülüğü: İşveren, işyerinde İSG'nin sağlanması, geliştirilmesi ve sürdürülebilir olması amacıyla, çalışma ortamında ortaya çıkabilecek tehlike ve riskler, koruyucu ve önleyici tedbirler, acil durumlarla ilgili yapılacaklar ile kendi yasal hak ve sorumlulukları konusunda çalışanları bilgilendirmelidir (İSGK, md. 16/1).
Çalışanların eğitimi yükümlülüğü: İlgili Kanun'un 17.maddesi uyarınca çalışanlara işe başlamadan önce, işte bir değişiklik olduğunda, kullanılan ekipmanlarda yahut teknolojide bir farklılık olması durumunda iş sağlığı ve güvenliği eğitimlerinin verilmesi de işverenin yerine getirmesi gereken yükümlülük ve sorumlulukları arasındadır (ISGK, md. 17/1).

Çalışanların görüşlerinin alınması ve katılımlarının sağlanması yükümlülüğü: İlgili Kanunun 18.maddesine göre işyerinde çalışanlar, çalışan temsilcileri ve destek elemanlarının İSG ile ilgili konularda fikirlerini beyan etmeleri, yapılan çalışmalara aktif olarak katılmaları için işverenin imkan sağlama zorunluluğu bulunmaktadır (İSGK, md. 18/1). Bu yükümlülük 6331 sayılı Kanunun 18. maddesi yanında, ISG konusunda çıkarılmış birçok yönetmelikte de özel olarak yer almaktadır.

Çalışan Temsilcisi Görevlendirme Yükümlülüğü; ISGK 20.maddesinde işverenin çalışanlar arasında, risklerin azaltılması hususunda işverene önerilerde bulunma, gereken tedbirler varsa bunların yapılmasını isteme ve ISG çalışmalarına katılma konusunda çalışanları temsil edecek çalışan temsilcisi görevlendirme yükümlülüğü düzenlenmiştir. Çalışan temsilcisi atamasının seçim yoluyla yapılması esastır. Seçim yoluyla yapılamıyorsa işveren tarafindan atama yoluyla belirlenebilme imkanı bulunmaktadır (İSGK, md. 20/1).

İSG Kurulu Oluşturma Yükümlülüğü: Elli ve daha çok sayıda çalışanın olduğu ve altı aydan daha uzun süren işlerin yapıldığı işyerinde işverenin, İSG konularının görüşüleceği, çalışmaların yapılacağı bir kurul oluşturmakla ilgili yükümlülüğü bulunmaktadır. İSG Kurulunca alınan mevzuata uygun kararların işveren tarafindan uygulaması zorunludur (ISGK, md. 22/1).

6331 Sayılı İSGK'da yer alan yükümlülüklerini yerine getirilmemesi işverenin hukuki idari ve cezai sorumluluklarla karşı karşıya kalmasına neden olur. İşveren her bir yükümlülüğü yerine getirmiş olsa dahi, özellikle İSGK'da önemli bir yere sahip olan proaktif yaklaşımın temellerini oluşturan risk değerlendirmesi ve risk değerlendirmesinin bir çıktısı olan acil durum yönetimi konusundaki sorumluluklarında zaafiyet göstermesi iş kazalarının doğmasına ve sonuçlarının ağırlaşmasına neden olabilir. $\mathrm{Bu}$ nedenle işveren bu konuda gerekli hassasiyeti göstermeli, risk değerlendirmesi ve acil durum prosedürlerini oluşturulup, dokümante ederek, gerekli görülenlerin bilgilendirmelerini evleviyetle yapmalıdır.

$\mathrm{Bu}$ bağlamda, işyerinde acil durum planını hazırlama esasları, önleyici, koruyucu tedbirler, tahliye, yangın, ilk yardım ve benzeri acil durum konularında yapılması gerekenler ile acil durumların güvenli bir şekilde yönetilebilmesi ve görevlendirilecek çalışanların belirlenmesi ile ilgili usul ve esasları düzenlemek amacıyla, Çalışma ve Sosyal Güvenlik Bakanlığı tarafından, İşyerlerinde Acil Durumlar Hakkında Yönetmelik (İADHK) çıkarılmıştır

\section{Acil Durum Kavramı}

İADHY'ye göre acil durum, “İşyerinin tamamında veya bir kısmında meydana gelebilecek yangın, patlama, tehlikeli kimyasal maddelerden kaynaklanan yayllım, doğal afet gibi acil müdahale, mücadele, ilkyardım veya tahliye gerektiren olayları" ifade etmektedir (İADHK, 2013). Bir işyerinde acil durum meydana geldiğinde ve meydana gelen olay tipik olarak zaman baskısı ve bilgi eksikliği ile bütünleştiğinde, ciddi sonuçlara yol açan olayın neden olduğu mülk ve can kayıplarını azaltan en 
önemli süreç “doğru karar vermek”tir (Levy ve Taji, 2007: 906907).

Acil durum müdahalesini uygun ve etkili kılmak için, karar verme sürecinden sorumlu karar vericilerin acil durumla hemen başa çıkabilmek için makul kararlar almaları gerekmektedir (Zhang, Wang ve Wang, 2018: 407). Alınan kararların makul ve etkili olabilmesi için çalışanlara verilen eğitim büyük önem arz etmektedir.

Son yıllarda yapılan acil durumlarda ilgili çalışmalar prosedürel "nasıl yapıldığını bil" değil, önermeye dayalı "bunu bil" üzerinedir. Afete müdahale yönetimini iyileştirmek için çeşitli önlemleri uygularken prosedür bilgisi gereklidir, ancak bu tür önlemleri uygulamak için öncelikle bunların işe yarayacağı sonucuna varmamız gerekir. Bunun için önerme bilgisi esastır. Burada önerme bilgisinden kasıt "haklı inançlar" ifadesidir (Frykmer vd., 2021: 3). Haklı inançlar işin sosyal boyutu olarak ele alınmaktadır.

Karar vericilerin psikolojik davranışları, stratejik manipülasyon davranışları, uzmanların işbirlikçi olmayan davranışları (Dong vd., 2016: 12) gibi farklı davranışlar acil durumlardaki karar verme sürecinde önemli roller oynamaktadır (Zhang, Wang ve Wang, 2018: 407). Karar vericilerin davranışları acil durumlarda doğru olduğuna karşı "haklı inançlar" olarak düşünmektedirler ancak kişisel olarak algılanan haklı inançların örgüt içerisinde doğru olup olmadığını irdelemek için bir grup olarak önceden acil durumlarla ve senaryolarla ilgili çalışmaların yapılması gerekir. Son yıllarda yapılan bazı çalışmalar bu noktaya parmak basmaktadır. Örneğin yapılan bir çalışmada acil durum ve afet müdahale yönetiminde müdahalelerin etkilerini veya "neyin işe yarayıp yaramadığını" inceleyerek sorunu analiz edilerek ve sahada iyileştirmeler önerebilecek tasarım bilgisinin geliştirilmesini destekleyen bir yaklaşımı savunmaktadır (Frykmer vd., 2021: 2).

Acil durumlarla baş edebilmenin bir başka sorunu ise çoklu ekip sistemlerinin acil durumların karmaşıklıklarını etkili bir şekilde yönetebilen çok yönlü sistemler olması gerekmektedir (Luciano, DeChurch ve Mathieu, 2015: 1080; Fleştea vd., 2017: 44).

İşverenin, işyerindeki acil durumlara ilişkin yükümlülükleri 18.06.2013 tarihli 28681 sayılı Resmi Gazete'de yayımlanan IADHY'de detaylı olarak yer almaktadır.

\subsection{Acil durumlarda işverenin yükümlülükleri}

Çalışma ortamında acil durum planının oluşturulması, önleyici, koruyucu faaliyetler, yangınla mücadele ve tahliye yöntemleri ile ilk yardım ve diğer acil durumlara müdahalede yapılması gerekenler ile bu sürecin sorunsuz yürütülmesi ve destek elemanlarının belirlenmesi ile ilgili usul ve esasları düzenlemek amacıyla çıkarılmış olan İADHY, İSGK'nın 11, 12 ve 30 uncu maddelerine dayanılarak hazırlanmıştır (İADHY, 2013).

İADHY'de işverenin yükümlülükleri başlığı altında yer alan yükümlülükler şu şekilde sıralanmaktadır;

-Çalışma şartları, kullanılan ekipmanlar, çevre koşulları değerlendirilerek olası acil durumları belirlemek

-Acil durumların etkilerinden çalışanları, işyeri ve çevresini korumak için önleyici ve sınırlandırıcı önlemler almak
-Işyerinde gerekli ölçüm yapmak ve değerlendirmelerde bulunmak

-Acil durum planı hazırlanması ve düzenli tatbikatların yapılmasını sağlamak

-Yeterli sayıda destek elemanını görevlendirmek ve muhtemel acil durumlara karşı hazırda bulundurmak

-Acil durumlarla ilgili işyeri dişından destek verebilecek kuruluşlarla irtibatta olabilecek düzenlemeler yapmak

-Enerji kaynaklarl ve acil durumlarda harici risk yaratabilecek sistemlerin devre dışı olmasıyla ilgili düzenlemeler yapmak

-Alt işveren, tedarikçiler, ziyaretçiler, geçici olarak görevlendirilen çalışanları acil durumlar hakkında bilgilendirmek.

6331 Sayılı İSGK'da acil durumlara karşı hazırlıklı olması zorunluluğu bulunan işverenin hazırlamakla yükümlü olduğu acil durum planının aşamaları İADHY'de belirlenmiştir.

\subsection{Acil durum planı hazırlama aşamaları}

İADHY'ye göre, acil durum planı, "İşyerlerinde meydana gelebilecek acil durumlarda yapllacak iş ve işlemler dahil bilgilerin ve uygulamaya yönelik eylemlerin yer aldiğl plan"dır (İADHY, md. 3/1-b).

Doktrinde Acil durum planı “işyeri dışındaki ilgili kuruluşların ekipleri işyerine intikal edene kadar geçen sürede durumun kontrol altına alınması, dışarıdan müdahale ve mücadele için gelen ekiplere yardımcı olunması, tüm işyeri çalışanları ve işyeri ile çevrenin güvenliğinin sağlanabilmesi için acil durum planları faaliyet koluna bakılmaksızın her işverenin hazırda bulundurması zorunlu olan bir plandır" şeklinde tanımlanmaktadır (Ravi K., vd., 2014: 263).

Acil durum planı, faaliyet alanına bakılmaksızın tüm işyerleri için tasarım ya da kuruluş sırasından itibaren acil durumların belirlenmesi, acil durumların olumsuz etkilerini önleyici ve sınırlandırıcı tedbirlerin alınması, görevlendirilecek destek elemanlarının belirlenmesi, acil durum müdahale ve tahliye yöntemlerinin oluşturulması, dokümantasyon, tatbikat ve acil durum planının yenilenmesi aşamalarına uygun olarak hazırlanır (İADHY, md. 7/1).

1-Acil durumların belirlenmesi: İADHY'de işverenin yükümlülükleriyle ilgili olarak acil durum planının hazırlanması aşamalarında ilk sırada "çalışma şartları, kullanılan makine ve teçhizatlar ile çevre koşulları göz önünde bulundurularak oluşabilecek ve çalışanlar ile çalışma ortamını ve çevresini olumsuz etkileyecek acil durumlar hususunda önceden bir değerlendirme yaparak, olası acil durumları belirleme" zorunluluğu yer almaktadır (İADHY, md. 5/1, a). Acil durumlarla mücadelede en etkin çözüm yolu, acil durum henüz oluşmadan işyeri olarak gerekli önlemleri alıp hazırlıklı olabilmektir. Acil durumlara karşı hazırlıklı olabilmek ve acil durumların vereceği zararları en az seviyeye ulaşabilmesi için yönetmelikte de işverenin birinci yükümlülüğü olan muhtemel acil durumları belirlerken, referans olarak alınabilecek hazırlanmış olan risk değerlendirmesi çalışması, doğal afetlerin meydana gelme ihtimali, tehlikeli kimyasal faktörler, yangın ve patlama riski ile ilkyardım ve tahliye yapılmasına gerek duyulacak durumların değerlendirilmesi gerekmektedir.

2-Önleyici ve sınırlandırıcı tedbirler: Acil durumlar belirlendikten sonra, toplu korunma önlemlerine kişisel 
koruyuculara göre öncelik verecek şekilde, acil durumların oluşmasını önlemek ve olumsuz etkilerini sınırlandırmak için alınacak önlemler belirlenerek acil durum planının hazırlanması aşamalarına devam edilmelidir (İADHY, md. 9).

3-Acil durum müdahale ve tahliye yöntemleri: İşyerinde herhangi bir acil durum söz konusu olduğunda İADHY 10. maddesine göre yapılacakların önceden planlı olması açısından, kargaşaya sebebiyet vermemek için, nasıl müdahale edilmesi gerektiğiyle ilgili yöntemlerin oluşturulması önem arz etmektedir. Belirlenen her bir acil durum için ayrı ayrı olmak üzere müdahale yöntemleri belirlenerek, oluşturulan prosedürler yazılı hale getirilmelidir. Ayrıca çalışanların acil durum sırasında güvenli yer olarak belirlenmiş olan alanda toplanabilmeleri için gerekli tahliye düzenlemelerinin de acil durum planında belirtilmesi gerekmektedir. Acil durumlarda yapılan müdahale ve tahliye prosedürleri 'Binaların Yangından Korunması Hakkındaki Yönetmelik " hükümleri göz önünde bulundurularak belirlenmelidir (İADHY, md. 10/1, 3, 5).

4-Görevlendirilecek çalışanların belirlenmesi: İşveren, acil durumlara müdahale ve acil durumlarla mücadele için üç farklı ekip görevlendirmelidir. Yönetmeliğe göre;

- Arama, kurtarma ve tahliye,

- Yanginla mücadele,

- İlkyardım gibi alanlarda, uygun donanıma sahip ve bu konularda eğitimli yeterli sayıda çalışandan oluşan ekipler oluşturulması gerekmektedir.

Oluşturulan ekipler arasındaki uyumun bulunması, gerektiğinde ortak eğitim ve tatbikatlar yapılması büyük önem taşır. Gerçekten, eşgüdümün sağlanmasının önemine vurgu yapan çoklu ekip sistemlerinde, öngörülemeyen tehlike durumlarında ve hızlı değişen şartlarda, esnek ancak hızlı karar almanın, iş sağlığ ve güvenliği açısından önemine özel olarak değinilmektedir (Mathieu, Marks ve Zaccaro 2001: 357-358).

İADY'nde oluşturulan acil durum ekipleri arasında eşgüdümün sağlanmasına ilişkin açık bir düzenleme bulunmamakta, ancak tebliğde belirtilmiş tehlike sınıflarına göre görevlendirilecek acil durum çalışanlarının sayısını belirlemektedir. Yönetmeliğin, 11. maddesine göre, çok tehlikeli sinıfta 30, tehlikeli sinıfta 40 ve az tehlikeli sinıfta yer alan işyerlerinde 50 çalışan için ; arama, kurtarma ve tahliye ile yangınla mücadelede görevlendirmek üzere birer destek elemanı belirlenmesi gerekmektedir (İADHY, md. 11/1). Diğer yandan İlkyardım Yönetmeliği uyarınca; çok tehlikeli sınıftaki işyerlerinde 10, tehlikeli sınıf için 15, az tehlikeli sınıf için de 20 kişiye en az bir ilkyardımcı belgesine sahip destek elemanı görevlendirilmesi zorunluluğu bulunmaktadır (İlkyardım Yönetmeliği, md. 19/1).

İşyerinde bu sayıları aşan çalışanların bulunması durumunda, tehlike sınıfına göre verilen sayıların her bir katlarında birer tane daha destek elemanı görevlendirir. İADHY'nin 11/3. maddesinde, belirtilen her bir konu için tehlike sınıfi ve çalışan sayısına göre birden çok çalışanın görevlendirilmesi gereken durumlarda, destek elemanlarından oluşan ekiplerin koordinasyon içinde görev yapmaları gerektiği belirtilmiş ve her ekipte bir ekip başının bulunması öngörülmüştür. Buna karşılık, 10 kişiden daha az çalışan kişinin bulunduğu az tehlikeli sınıftaki işyerleri için, tüm ekipler adına yeterli donanıma ve belgeye sahip olan bir kişi görevlendirilmesi yeterlidir.

e-ISSN: 2148-2683
5-Dokümantasyon: Acil durumlar konusunda yapılan tüm çalışmaların yazılı hale getirilmesi önemli olduğu gibi, acil durum planının dokümantasyonunun da mevzuata uygunluğu ile hazırlanan krokinin işyerinde herkes tarafindan rahatça fark edilebilecek şekilde bulundurulması ayrı bir önem arz etmektedir.

-İşyerinin adı, unvan ve adresi.

-Hazırlayan kişilerin isim, soy isim ve unvanları.

-Planın oluşturulduğu tarih ile geçerlilik tarihi.

-İşyerine özgü belirlenmiş olan acil durumlar.

-Her bir acil durumda alınacak önleyici ve sınırlandırıcı önlemler.

-Her bir acil durumda yapılacak müdahale ve tahliye prosedürleri

-Yangınla mücadele ve ilkyardım ekipmanlarının bulunduğu yerler, acil çıkış yolları, kapıları, merdivenleri vs, toplanma alanı, uyarı sistemlerinin gösterildiği yerler ile destek elemanları varsa yedeklerinin isim, soy isim, unvan, görev ve iletişim bilgileriyle beraber acil durumlarda irtibat sağlanacak işyeri dışındaki kuruluşların numaralarının bulunduğu bir krokinin dokümantasyon olarak bulundurulması gerekmektedir. Hazırlanan acil durum planının sayfalarına numara verilip; hazırlayan kişiler tarafından her sayfası paraflanıp, son sayfası imzalanır ve acil durumlarda müdahale ve mücadelede görevli ekiplerin kolaylıkla ulaşabilecekleri bir şekilde işyerinde saklanır (İADHY, md. 12/1, 2, 3).

6- Tatbikat; Hazırlanan acil durum planının her bir aşamasının gerçekte uygulanabilir olup olmadığının kontrolü ve acil durum planında bir hata veya eksikliğin tespit edilebilmesi için işyerinin tehlike sınıfına bakılmaksızın, tüm işyerlerinde yılda en az bir defa olmak üzere tatbikatlar düzenlenir. Tatbikat sonrasında gerekli görülmesi durumunda düzeltici ve önleyici faaliyetler uygulanır, gerekli düzeltmeler yapılır. Tatbikatın tarihi, süresi, görülen eksikliklerin yer aldığ 1 tatbikat raporu formu hazırlanır (İADHY, md. 13/1).

7-Acil Durum Planının Yenilenmesi; İşyerinin tehlike ve risklerine özgü belirlenmiş olan acil durumlar ya da öngörülemeyen acil durumlara sebep olabilecek değişikliklerin meydana gelmesi durumunda acil durum planı tamamı veya bir bölümü yeniden hazırlanır. Hazırlanan acil durum planına aykırı her hangi bir durum ya da değişiklik söz konusu olmadığında ise, çok tehlikeli sınıfta 2 yılda bir, tehlikeli sınıfta 4 yılda bir ve az tehlikeli sınıfta 6 yılda bir planın yenilenmesi gerektiği ifade edilmiştir ((İADHY, md. 14/1, 2).

\section{Sonuç}

Olası acil durumlara karşı her daim hazır olunması, zararlarının etkin bir şekilde sınırlandırılması öngörülebilir tehlikelerin önüne geçilmesi için önlemlerin alınması amacıyla planlama yapılması iş sağlığı ve güvenliğinin önleyici yaklaşımının bir gereğidir. Bu planlamayı işverenin inisiyatifine bırakmak, çoğu zaman çalışanların işyeri tehlikelerine karşı korumasız kalması sonucunu doğurur. Nitekim, acil durum planlarını hazırlama yükümlülüğü, İş Kanunu kapsamına giren tüm işyerleri için mevzuatımızda yer almaktaydı. Fakat 6331 Sayılı ISGK' dan önce acil durum planının hazırlanmamış olması herhangi bir müeyyideye bağlanmamıştı ve bu nedenle de işveren, çoğu zaman bu yükümlülüğünü yerine getirme ihtiyacı duymamaktaydi.

6331 Sayılı İSGK'nın kabulü ile birlikte acil durum planı yükümlülüğünün kapsamı daha da genişletilmiş; bu 814 
yükümlülüğün yerine getirilmemesi yaptırıma bağlanmıștır. Böylece, ISGK kapsamına girmeyen iş ve işyerleri hariç tutularak, faaliyet alanına bakılmadan özel sektör ve kamuya ait olan bütün işyerlerine acil durum planı hazırlama yükümlülüğü getirilmiştir. $\mathrm{Bu}$ yükümlülüğün düzenlendiği Kanunun 11. maddesi uyarınca işverenler, iş sağlığı ve güvenliği yönünden acil durum planı hazırlamakla yükümlüdür.

İşyerlerinde 6331 Sayılı İSGK hükümlerinin uygulanıp uygulanmadığının ya da ne seviyede uygulandığının izlenmesi ve denetlenmesi, İSG konusunda denetim yetkisi bulunan Bakanlık iş müfettişleri tarafından gerçekleştirilir (İSGK, md.24).

Şekil 1'de gösterilen 2021 y1lı acil durumlarla ilgili konularda eksik çalışmaları bulunan işverenlere uygulanacak olan idari para cezalarına yer verilmiştir Aile, Çalışma ve Sosyal Hizmetler Bakanlığı (AÇSHB), 2021). İSGK madde 11'e göre işverenin acil durumlarını belirlememesi, acil durum planı hazırlamaması, acil durumlarla ilgili tedbir almaması, acil durum ekipmanlarını bulundurmaması, destek elemanı görevlendirmemesi veya işyeri dışındaki kuruluşlarla işbirliği

yapmaması durumunda 10 kişiden az çalışanı olan çok tehlikeli sınıfta bir işyeri her ay için 3832 TL, 10-49 arasında çalışan sayısı bulunan çok tehlikeli sınıfta bir işyeri 5110 TL, 50 ve üzerinde çalışanı olan çok tehlikeli sınıfta bir işyeri ise 7665 TL idari para cezası ödemek zorundadır. Aykırılığın devam ettiği her ay için ise cezalar katlanarak artırılmaktadır (AÇSHB, 2021). İşveren Kkanunun 12.maddesini oluşturan tahliye ile ilgili her bir aykırı durum için aynı şekilde idari para cezası ödemekle yükümlüdür.

Sadece Acil durum yönetiminin oluşturulması ve acil durum planının hazırlanmış olması işverenin sorumluluklarını ortadan kaldırmamaktadır. İşverenlerin İSGK'ya göre öngörülen idari para cezalarının haricinde, hazırlanan acil durum planlarının uygulanabilir olması, işyerinde olası acil durumlara karşı gerçek anlamda hazırlıklı olması büyük önem arz etmektedir. Acil durum planları yalnızca dökümantasyon olarak bulundurulma amaçlı değil de, risk değerlendirmesinin bir çıktısı olarak kabul edilen acil durum planlarındaki önleyici ve sınırlandırıcı tedbirlerin alınması acil durumların yaşanması veya zararının azaltılması konusunda etkin olacaktır ve böylece olası istenmeyen durumlar ve kayıpların önüne geçilebilecektir. İstenmeyen durumlarda kusurlu olarak görülebilecek işverenlerin hukuki ve cezai sorumlulukları kapsamında da acil durum yönetimi konusunda bilinçli olmaları, bu konuya hassasiyet göstermeleri gerekmektedir.

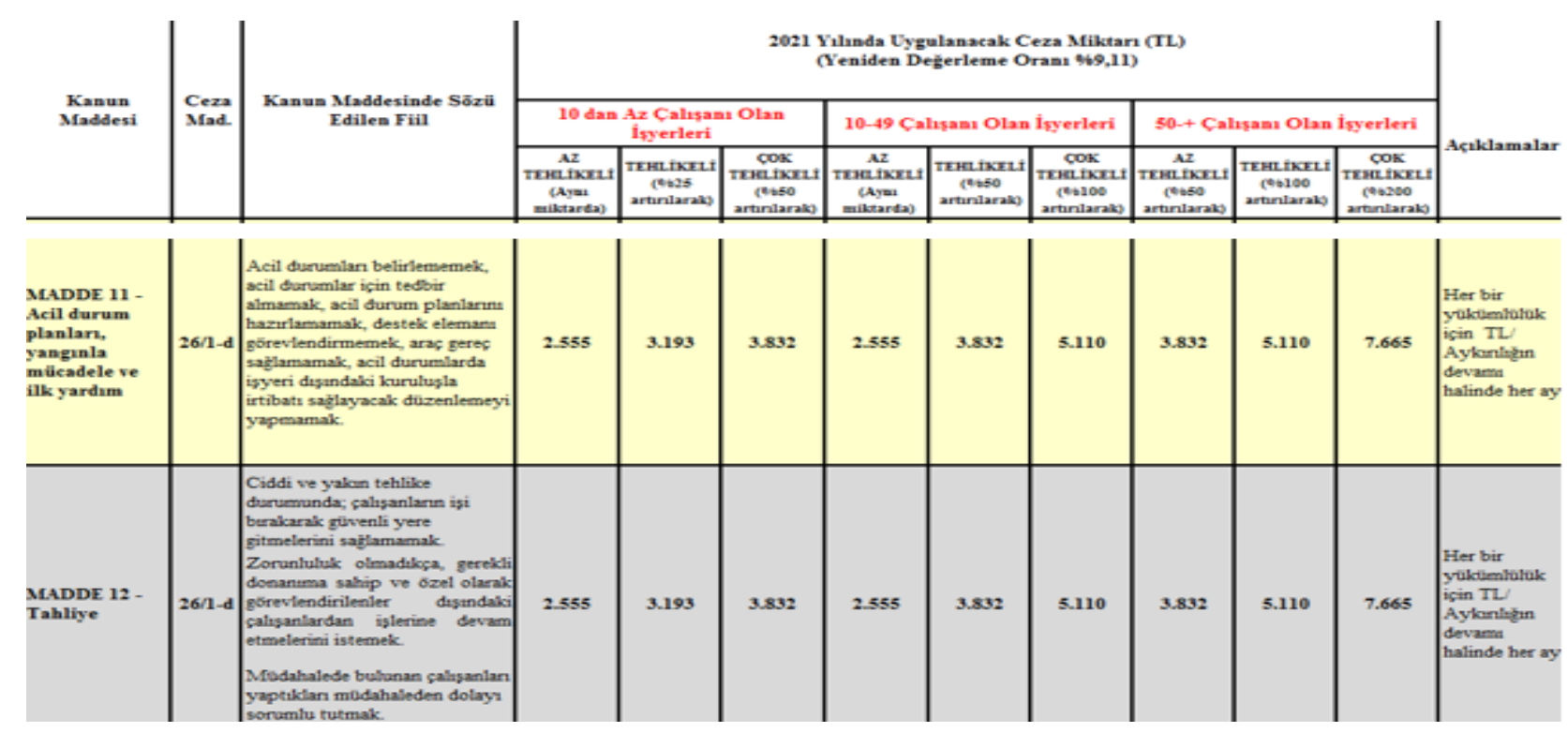

Şekil 1: 2021 yılında acil durumlarla ilgili işverenlere uygulanacak idari para cezaları. 


\section{Kaynakça}

1475 Sayılı İş Kanunu, Resmi Gazete, S: 13943, 25.08.1971.

1965-1967 İşçi Sağlığı ve İş Güvenliği Faaliyetlerini Geliştirme Planı, Çalışma Bakanlığı İşçi Sağlığı Genel Müdürlüğü, Ankara 1965

3008 Sayılı İş Kanunu, Resmi Gazete, S: 3330, 15.06.1936.

4857 Sayılı İș Kanunu, Resmi Gazete, S: 25134, 10.06.2003.

6098 Sayılı Türk Borçlar Kanunu, Resmi Gazete, S: 27836, 04.02.1011.

6331 Sayılı İş Sağlığı ve Güvenliği Kanunu, Resmi Gazete, S: 28339, 30.06.2012.

931 Sayılı İş Kanunu, Resmi Gazete, S: 12953, 18.07.1968.

Aile, Çalışma ve Sosyal Hizmetler Bakanlığı, (AÇSHB), (2021), 6331 Sayılı İSG Kanununa Göre 2021 Y1lında Uygulanacak İdari Para Cezaları https://www.ailevecalisma.gov.tr/isggm/hizmetlerimiz/idaripara-cezalari/ (Erişim tarihi: 21.03.2021).

Binaların Yangından Korunması Hakkında Yönetmelik, Resmi Gazete, S: 26735, 19.12.2007.

Dong, Y., Zhang, H., \& Herrera-Viedma, E. (2016). Integrating experts' weights generated dynamically into the consensus reaching process and its applications in managing noncooperative behaviors. Decision Support Systems, 84, 1-15.

Fleştea, A. M., Fodor, O. C., Curşeu, P. L., \& Miclea, M. (2017). 'We didn't know anything, it was a mess!'Emergent structures and the effectiveness of a rescue operation multiteam system. Ergonomics, 60(1), 44-58.

Frykmer, T., Tehler, H., Uhr, C., \& Wester, M. (2021). Advancing the Field of Disaster Response Management: Toward a Design Science Approach. International Journal of Disaster Risk Science, 1-12.

İlkyardım Yönetmeliği, Resmi Gazete, S: 29429, 29.07.2015.
İşyerlerinde Acil Durumlar Hakkında Yönetmelik, Resmi Gazete, S: 28681, 18.06.2013.

Kılkış, İ. (2013). İş sağlığı ve güvenliğinde yeni dönem: 6331 sayılı İş Sağlığı ve Güvenliği Kanunu (İSGK). İş, Güç Endüstri İlişkileri ve Insan Kaynakları Dergisi, 15(1), 17-41.

Korkmaz, A., Avsallı, H., (2012), Çalışma Hayatında Yeni Bir Dönem:6331 Sayılı İş Sağlığı ve Güvenliği Yasas1, SDÜ Fen Edebiyat Fakültesi, Sosyal Bilimler Dergisi, 26, 153- 167.

Levy, J.K., \& K. Taji. (2007). Group decision support for hazards planning and emergency management: A Group Analytic Network Process (GANP) approach. Mathematical and Computer Modelling 46(7): 906-917.

Luciano, M. M., DeChurch, L. A., \& Mathieu, J. E. (2018). Multiteam systems: A structural framework and meso-theory of system functioning. Journal of Management, 44(3), 10651096.

Marks, M. A., Mathieu, J. E., \& Zaccaro, S. J. (2001). A temporally based framework and taxonomy of team processes. Academy of management review, 26(3), 356-376.

Ozay, M. E., \& Coskun, S. (2017). Analysıs Of Occupational Health And Safety Data Between 2003-2015 In Turkey. Journal Of Business Economics And Finance, 6(4), 375-385.

Özdemir, E.: İş Sağlığı ve Güvenliği Hukuku, İstanbul 2014

Ravi K., Bhola R., Akshay V., Satish R., Santosh P., \& Rajat A., (2014). Auotmation Of Emergency Response For Petroleum Oil Storage Terminals. Safety Science, Sayı: 72, Sayfa: 263.

Süzek, Sarper, İş Güvenliği Hukuku, Ankara 1985

Tunçomağ, K., (1972). Türk İş Hukukunda Son Gelişmeler, İstanbul Üniversitesi Hukuk Fakültesi Mecmuas1, Cilt: 37, Say1: 1-4, 243-261.

Zhang, Z. X., Wang, L., \& Wang, Y. M. (2018). An emergency decision making method based on prospect theory for different emergency situations. International Journal of Disaster Risk Science, 9(3), 407-420. 